原著

\title{
未破裂脳動脈瘤手術成績の検討
}

$$
\begin{aligned}
& \text { 小松 洋治1, 兵頭 明 夫, 吉 沢 卓 }{ }^{1} \\
& \text { 能勢 忠男, 小林栄喜, 目黑 琴生 }{ }^{3} \\
& \text { 小野 幸雄, 松木 孝之, 白井 鎮 } 夫^{6}
\end{aligned}
$$

\section{Surgical Prognosis of Unruptured Intracranial Arterial Aneurysms Report of 76 Cases}

Yoji Komatsu, M.D., ${ }^{1}$ Akio Hyodo, M.D., ${ }^{1}$ Suguru Yoshizawa, M.D., ${ }^{1}$ Tadao Nose, M.D., ${ }^{1}$ Eiki Kobayashi, M.D., ${ }^{2}$ Kotoo Meguro, M.D., ${ }^{3}$ Yukio Ono, M.D., ${ }^{4}$ Takayuki MATsuki, M.D., ${ }^{5}$ and Shizuo ShiraI, M.D. ${ }^{6}$

${ }^{1}$ Department of Neurosurgery, Institute of Clinical Medicine, University of Tsukuba, ${ }^{2}$ Department of Neurosurgery, Tsukuba Memorial Hospital,

${ }^{3}$ Department of Neurosurgery, Tsukuba Medical Center,

${ }^{4}$ Department of Neurosurgery, Kensei General Hospital,

${ }^{5}$ Department of Neurosurgery, Kobari Hospital, and

${ }^{6}$ Department of Neurosurgery, Sohjinkai Hospital, Ibaraki, Japan

Summary : A series of surgical treatment is presented of 76 patients with unruptured cerebral aneurysms of anterior circulation. The age of patients varied from 34 to 76 (mean 58.8) and there were considerably more females than males (49 against 27 ). There were 89 aneurysms and 79 surgical treatments were performed. In 39 patients carotid angiograms were performed because of ischemic cerebrovascular disease, in 22 patients of ruptured aneurysm surgery was performed in two or more stages, and surgery was performed in eight patients of cranial nerve palsy, and in seven patients of trauma or chronic headache.

There were three deaths due to infarction and delayed intracranial hemorrhage within 30 days after surgery (mortality $3.9 \%$ ). Transient morbidity occured in four patients (5.3\%), and parmanent morbidity occurred in two patients $(2.6 \%)$.

The authors analyze the risk factors for surgical treatment of unruptured aneurysms. They indicate four risk factors for both mortality and morbidity; ischemic cerbrovascular disease, diabetes mellitus, low density area on CT, and arteriorsclerotic changes on angiogram. Another three factors are indicated for mortality: patients over 70 years old, male and aneurysm on middle cerebral artery.

Seven cases of this series had extracranial carotid stenosis in the same side of the aneurysm. Carotid endarterectomy was performed prior to aneurysmal clipping in five patients, and their postoperative courses were excellent. In two patients, clipping was performed prior to endarterectomy and transient morbidity occurred in one. These results suggest that management of cerebral blood flow of ischemic brain may improve surgical prognosis of patients with ischemic cerebrovascular disease.

They also indicate that surgery for an unruptured aneurysm associated with ischemic cerebrovascular disease requires more cautions and delicate operative techniques, and improvement of cere-
Key words :

- unruptured aneurysm

- ischemic cerebrovascular disease

- elderly patient

- surgical treatment

1筑波大学 脳神経外科, ${ }^{2}$ 筑波記念病院 脳神経外科, ${ }^{3}$ 筑波メディカルセンター脳神経外科, ${ }^{4}$ 県西総合病院 脳神経外科, ${ }^{5}$ 小張病院 脳神経外科, ${ }^{6}$ 宗仁会病院 脳神経外科(受稿日 1991.6.6)

〔連絡先： $\overline{7} 309-12$ 茨城県西茨城郡岩瀬町鍬田 604 県西総合病院脳神経外科 小松洋治] 
bral blood flow should be tried prior to the clipping of an aneurysm if possible. Surgery on older patient should be performed only in selected cases where the patient has a risk of future aneurysmal rupture.

\section{はじめに}

破裂脳動脈瘤の治療には現在もなお多くの困難な問題が あり，転帰不良な症例も少なくない(4)17)。脳動脈瘤が未破 裂のうちに診断され，そして安全に治療されることは，ひ
とつの理想的な方法である.この見地から，われわれは， 未破裂脳動脈瘤に対して積極的に治療を行ってきた。今回 その手術成績を分析し，転帰不良因子についての検討を行 い，また手術成績向上のための方策についても検討したの で報告する。

Table 1 Summary of 76 patients with unruptured cerebral aneurysm (1)

\begin{tabular}{|c|c|c|c|c|c|c|c|c|c|c|}
\hline Case & Age & Sex & $\begin{array}{l}\text { Aneurysm } \\
\text { site }\end{array}$ & size & $\begin{array}{l}\text { Original } \\
\text { disease }\end{array}$ & HT & $\mathrm{DM}$ & $\begin{array}{c}\text { Pre ope. } \\
\text { ADL }\end{array}$ & $\begin{array}{l}\text { Outcome } \\
\text { (ADL) }\end{array}$ & Comment \\
\hline 1 & 34 & $M$ & Rt MCA & $7 \mathrm{~mm}$ & Infarction & - & - & 1 & 1 & \\
\hline 2 & 34 & $\mathrm{~F}$ & Rt ICOpt & 10 & Abducence palsy & + & - & 1 & 1 & \\
\hline 3 & 37 & $F$ & Lt ICPC & 3 & Oclomotor palsy & - & - & 1 & 1 & \\
\hline 4 & 38 & $M$ & Lt ICPC & 4 & Ruptured aneurysm & - & - & 2 & 1 & \\
\hline 5 & 41 & $\mathrm{~F}$ & Rt dist-A & 15 & Headache & - & - & 1 & 1 & \\
\hline 6 & 41 & $\mathrm{~F}$ & Lt ICAcho & 5 & Ruptured aneurysm & + & + & 2 & 1 & \\
\hline 7 & 42 & $\mathrm{~F}$ & Lt ICAcho & 12 & Ruptured aneurysm & + & - & 3 & 2 & \\
\hline 8 & 43 & $M$ & Lt MCA & 5 & AVM & - & - & 1 & 1 & \\
\hline 9 & 44 & $M$ & Lt MCA & 3 & Ruptured aneurysm & - & - & 2 & 1 & \\
\hline 10 & 44 & $\mathrm{~F}$ & A com & 5 & Convulsion & - & - & 1 & 1 & \\
\hline 11 & 45 & $F$ & Rt MCA & 7 & Ruptured aneurysm & + & - & 3 & 2 & polycystic kidney \\
\hline 12 & 45 & $\mathrm{~F}$ & Rt ICPC & 3 & Ruptured aneurysm & + & - & 1 & 1 & \\
\hline 13 & 46 & M & Lt ICAcho & 3 & Infarction & + & - & 2 & 2 & \\
\hline 14 & 46 & $\mathrm{~F}$ & Lt MCA & 7 & Ruptured aneurysm & + & - & 1 & 1 & \\
\hline 15 & 47 & $F$ & Lt dist-A & 6 & Ruptured aneurysm & - & - & 2 & 1 & \\
\hline 16 & 49 & $F$ & Lt ICPC & 10 & Ruptured aneurysm & + & - & 1 & 1 & \\
\hline 17 & 50 & $\mathrm{~F}$ & Rt MCA & 9 & Ruptured aneurysm & + & + & 2 & 2 & \\
\hline 18 & 51 & $M$ & Rt ICPC & 4 & Oclomotor palsy & - & - & 1 & 1 & \\
\hline 19 & 51 & $\mathrm{~F}$ & Rt ICPC & 3 & TIA & - & + & 1 & 1 & ${ }^{*}$ Wrapping \\
\hline 20 & 51 & $\mathrm{~F}$ & Lt ICPC & 3 & Ruptured aneurysm & - & - & 2 & 1 & \\
\hline 21 & 52 & $F$ & Lt MCA & 7 & Ruptured aneurysm & - & - & 1 & 1 & \\
\hline \multirow[t]{2}{*}{22} & 53 & M & Lt MCA & 6 & Infarction & + & + & 2 & 2 & transient morbidity \\
\hline & & & Lt ICPC & 3 & & & & & & \\
\hline 23 & 54 & $M$ & Rt ICPC & 3 & Infarction & + & - & 2 & 1 & \\
\hline 24 & 54 & $\mathrm{~F}$ & Lt MCA & 4 & Infarction & + & - & 2 & 1 & clip $\rightarrow$ CEA \\
\hline 25 & 54 & $\mathrm{~F}$ & Lt MCA & 5 & Infarction, Old ICH & + & + & 2 & 2 & transient morbidity \\
\hline 26 & 55 & $M$ & Rt MCA 1 & 10 & Ruptured aneurysm & - & - & 1 & 1 & \\
\hline 27 & 55 & $M$ & Rt ICPC & 6 & Infarction & + & + & 2 & 2 & \\
\hline 28 & 56 & M & Lt ICbif & 3 & Infarction & + & - & 2 & 1 & CEA $\rightarrow$ clip \\
\hline 29 & 57 & $M$ & Rt MCA & 4 & Malignant lymphoma & + & - & 1 & 1 & \\
\hline \multirow[t]{2}{*}{30} & 58 & $M$ & Lt ICPC & 4 & Infarction & - & + & 2 & 1 & \\
\hline & & & Lt MCA & 6 & & & & & & \\
\hline \multirow[t]{2}{*}{31} & 58 & $\mathrm{~F}$ & Rt MCA & 5 & Infarction & + & - & 2 & 1 & two stage surgery \\
\hline & & & Lt MCA & 3 & & & & & & \\
\hline 32 & 58 & $\mathrm{~F}$ & Rt MCA & 4 & Ruptured aneurysm & - & - & 2 & 2 & \\
\hline \multirow[t]{3}{*}{33} & 58 & $F$ & Lt ICPC & 7 & Infarction & + & - & 1 & 1 & two stage surgery \\
\hline & & & Lt MCA & 2 & & & & & & \\
\hline & & & Rt MCA & 5 & & & & & & \\
\hline 34 & 58 & $\mathrm{~F}$ & Rt ICPC & 8 & TIA & + & + & 1 & 1 & CEA $\rightarrow$ clip \\
\hline 35 & 59 & $\mathrm{M}$ & Rt MCA & 4 & Infarction & + & - & 2 & 2 & \\
\hline 36 & 59 & $\mathrm{M}$ & Rt MCA & 3 & Ruptured aneurysm & - & - & 1 & 1 & \\
\hline 37 & 59 & $\mathrm{~F}$ & Lt ICPC & 5 & $\mathrm{ICH}$ & + & - & 1 & 1 & \\
\hline
\end{tabular}

A com: anterior communicating artery, dist-A: distal of anterior cerebral artery, ICAcho: internal carotid artery-anterior choroidal artery, ICOpth: internal carotid arteryopthalmic artery, ICPC: internal carotid artery-posterior communicating artery, MCA: middle cerebral artery 


\section{対象および方法}

対象は, 1983 年から 1990年の間に, 筑波大学脳神経外 科および関連施設でWillis 輪前半部の未破裂脳動脈瘤直 達手術を施行した 76 症例である. 破裂脳動脈瘤との同時 手術例は除外した。男性 27 例，女性 49 例. 年齢は，34 歳から 76 歳で, 平均 58.8 歳である (Table 1, 2).

未破裂脳動脈瘤診断の契機は，虚血性脳血管障害の精査 によるもの 39 例, 破裂脳動脈瘤に合併したもの 22 例, 脳 神経症状によるもの 8 例, 外傷や慢性的頭痛の精査などに よるもの 7 例である.
動脈瘤は 89 個であり，その部位は，内頸動脈系 43 個， 中大脳動脈系 37 個, 前交通動脈系 5 個, 前大脳動脈系 4 個であった.

手術は 79 回行われ，86瘤に対してクリッピングを行い 3 瘤に対してラッピングを行った。手術は大部分の症例で は, pterional approach で施行したが, 前大脳動脈遠位部 動脈瘤の全例および前交通動脈瘤の 1 例では interhemispheric approach で施行した ${ }^{10)}$ 。また， 7 例では動脈瘤の 処置と近接した時期に頸動脈内膜剝離術 (CEA)を，1例は 浅側頭動脈一中大脳動脈吻合術を同時に施行した.

手術成績は，術前より改善がみられたか，あるいは変化

Table 2 Summary of 76 patients with unruptured cerebral aneurysm (2)

\begin{tabular}{|c|c|c|c|c|c|c|c|c|c|c|}
\hline Case & Age & Sex & $\begin{array}{l}\text { Aneurysn } \\
\text { site } \\
\end{array}$ & $\begin{array}{l}\text { mal } \\
\text { size }\end{array}$ & $\begin{array}{l}\text { Original } \\
\text { disease }\end{array}$ & $\mathrm{HT}$ & $\mathrm{DM}$ & $\begin{array}{c}\text { Pre ope. } \\
\text { ADL }\end{array}$ & $\begin{array}{l}\text { Outcome } \\
\text { (ADL) }\end{array}$ & Comment \\
\hline 38 & 60 & $M$ & Lt $M C A^{*}$ & $5 \mathrm{~mm}$ & Infarction & + & - & 3 & 2 & *wrapping \\
\hline 39 & 60 & $M$ & Rt ICPC & 7 & Infarction & + & - & 2 & 2 & \\
\hline 40 & 60 & $\mathrm{~F}$ & $\begin{array}{l}\text { A com } \\
\text { Rt MCA }\end{array}$ & $\begin{array}{l}5 \\
3\end{array}$ & VBI & + & + & 1 & 3 & dysorientation \\
\hline 41 & 60 & $F$ & Lt ICPC & 3 & Infarction & + & - & 2 & 1 & \\
\hline 42 & 60 & $F$ & Rt ICPC & 6 & Oclomotor palsy & - & - & 1 & 1 & \\
\hline 43 & 61 & $F$ & Lt dist-A & 5 & VBI & + & + & 1 & 1 & \\
\hline 44 & 61 & $\mathrm{~F}$ & Rt MCA & 4 & TIA & + & - & 1 & 1 & \\
\hline 45 & 62 & $F$ & Lt ICPC & 5 & Oclomotor palsy & - & - & 1 & 1 & \\
\hline 46 & 62 & $\mathrm{~F}$ & Rt ICPC & 10 & Oclomotor palsy & + & - & 1 & 1 & \\
\hline 47 & 63 & $\mathrm{~F}$ & Lt MCA & 15 & Headache & - & - & 1 & 1 & \\
\hline 48 & 64 & M & $\begin{array}{l}\text { Lt ICPC } \\
\text { Lt MCA }\end{array}$ & $\begin{array}{l}6 \\
4\end{array}$ & Infarction & + & + & 3 & 2 & $\begin{array}{l}\text { clip } \rightarrow \text { CEA, } \\
\text { transient morbidity }\end{array}$ \\
\hline 49 & 64 & $M$ & $\begin{array}{l}\text { Lt ICAcho } \\
\text { Rt ICPC }\end{array}$ & $\begin{array}{l}3 \\
6\end{array}$ & Oclomotor palsy & + & - & 1 & 1 & two stage surgery \\
\hline 50 & 64 & $F$ & Rt ICOpt & 4 & Oclomotor palsy & + & + & 1 & 1 & \\
\hline 51 & 64 & $F$ & A com & 3 & Infarction & + & - & 2 & 2 & \\
\hline 52 & 64 & $F$ & Rt ICOpt & 6 & TIA & - & - & 1 & 1 & 1/4 anopia \\
\hline 53 & 65 & $F$ & Rt MCA & 7 & Ruptured aneurysm & + & - & 2 & 2 & \\
\hline 54 & 66 & M & Rt ICOpth & 6 & Ruptured aneurysm & - & - & 1 & 1 & \\
\hline 55 & 66 & $M$ & Lt MCA & 4 & TIA & + & - & 1 & 1 & clip \& STA-MCA anastomosis \\
\hline 56 & 66 & $F$ & Rt MCA & 10 & Infarction & + & - & 1 & 1 & transient psychiatric sympton \\
\hline 57 & 67 & $\mathrm{~F}$ & Lt MCA & 5 & Ruptured aneurysm & - & - & 2 & 1 & \\
\hline 58 & 67 & $F$ & $\begin{array}{l}\text { Lt MCA } \\
\text { Lt ICPC }\end{array}$ & $\begin{array}{l}5 \\
4\end{array}$ & Ruptured aneurysm & + & - & 3 & 2 & \\
\hline 59 & 68 & M & A com & 11 & Infarction & + & + & 2 & 2 & CEA $\rightarrow$ clip \\
\hline 60 & 68 & $M$ & Lt MCA & 7 & Infarction, NPH & + & - & 2 & death (9 day & y) Delayed $\mathrm{ICH}$, pneumosia \\
\hline 61 & 70 & $M$ & Rt MCA & 12 & Infarction & + & + & 3 & death(20 day & y) Infarction, Glbleeding \\
\hline 62 & 70 & $\mathrm{~F}$ & A com & 5 & Infarction & + & - & 3 & 3 & \\
\hline 63 & 72 & $F$ & Rt ICPC & 3 & Infarction & + & - & 2 & 2 & \\
\hline 64 & 72 & $F$ & $\begin{array}{l}\text { Rt dist-A } \\
\text { Lt ICPC }\end{array}$ & $\begin{array}{l}4 \\
8\end{array}$ & Infarction & + & + & 3 & 3 & \\
\hline 65 & 72 & $F$ & Rt ICPC & 5 & Infarction & + & - & 1 & 1 & \\
\hline 66 & 72 & $F$ & Lt ICPC & 5 & Infarction & + & - & 1 & 1 & \\
\hline 67 & 73 & $M$ & Lt MCA & 7 & Infarction & + & + & 1 & death( 25 day & y) Infarction, pneumonia \\
\hline 68 & 73 & $F$ & Lt ICPC & 4 & Infarction & + & - & 2 & 2 & CEA $\rightarrow$ clip \\
\hline 69 & 73 & $\mathrm{~F}$ & Rt MCA & 4 & Ruptured aneurysm & + & - & 3 & 3 & \\
\hline 70 & 73 & $F$ & Rt ICPC & 12 & $\mathrm{ICH}$ & + & - & 3 & 2 & \\
\hline 71 & 74 & $F$ & Lt ICPC & 5 & LOC attack & + & + & 1 & 1 & \\
\hline 72 & 75 & $\mathrm{~F}$ & $\begin{array}{l}\text { Lt ICPC } \\
\text { Lt MCA(M1) } \\
\text { Lt MCA(M2) }\end{array}$ & $\begin{array}{l}3 \\
2 \\
7\end{array}$ & Infarction & + & - & 2 & 2 & \\
\hline 73 & 75 & $F$ & Rt ICPC & 3 & Ruptured aneurysm & + & + & 3 & 2 & \\
\hline 74 & 76 & $M$ & Rt ICPC & 5 & Infarction & + & + & 2 & 1 & \\
\hline 75 & 76 & $M$ & Rt ICPC & 6 & Infarction & + & - & 1 & 1 & CEA $\rightarrow$ clip \\
\hline 76 & 76 & $F$ & $\begin{array}{l}\text { Lt MCA* } \\
\text { Lt ICPC }\end{array}$ & $\begin{array}{l}2 \\
5\end{array}$ & Infarction & + & + & 2 & 2 & *wrapping \\
\hline
\end{tabular}


Table 3 Surgical result of 76 patients

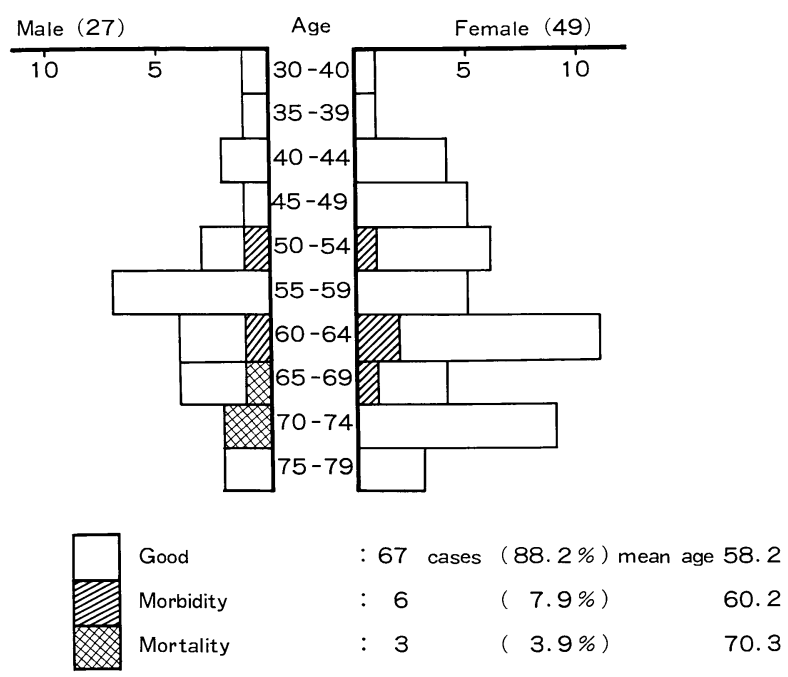

のない症例をgood，新たな障害をきたした症例を morbidity, 術後 1 力月以内の死亡症例を mortality とした. morbidityについては, transientと permanentに分けた検 討も行った. またADLについては, 脳卒中の外科研究会 の基準により，術前および術後 2 力月の時点で評価した。

治療成績との関連を患者因子, 動脈瘤因子, 神経放射線 学的因子に分けて検討した，患者因子として，年齢，性， 術前 $\mathrm{ADL}$, 原疾患, 高血圧症の合併, 糖尿病の合併を検 討項目とした。動脈瘤因子として, 側, 部位, 大きさ (脳 血管撮影上の長径)を検討した。神経放射線学的因子とし て，CT での低呼吸域(実測として $9 \mathrm{~mm}$ 以上)，脳血管撮 影で壁不整，狭窄，elongation などの動脈硬化所見の存在 の有無について検討した.

虚血性脳血管障害を原疾患とした症例のうち，動脈瘤に
対する手術と近接して CEA を施行した 7 症例では，その 成績についての検討も加えた。

\section{結 果}

\section{1. 手術成績および不良症例の検討}

手術成績は, good が 67 症例 (88.2\%), morbidity が 6 症例 (7.9\%), mortality が 3 症例 (3.9\%) であった（Table 3).

morbidity のうち 4 症例は一過性であり, 新たな梗塞巣 を生じたもの 2 例 (症例 22,48 ), 術前からの梗塞症状の一 過性の悪化 1 例 (症例 54), 脳腫脹 1 例 (症例 56) であった。 2 症例は永続的で，新たな脳梗塞 1 例 (症例 40)，四分の一 盲 1 例 (症例 52)であった. mortalityのうち 2 例は, 術後 に新たな脳梗塞を生じ意識障害が遷延し肺炎，消化管出血 などの合併症で術後 20，25 日目に死亡 (症例 61,67)。1 例は，術後 2 日目に遅発性の脳内出血をきたし肺炎で 9 日 目に死亡した (症例 60). 未破裂脳動脈瘤手術により障害 をきたした 9 症例の直接的な原因として，動脈系の血流障 害 5 例, retractionの不適切 2 例，クリップによる視神経 圧迫 1 例，シルビウス静脈の損傷 1 例と推測された (Table 4)

\section{2. 患者因子について (Table 5)}

転帰ごとの平均年齢は, good が 58.2 歳, morbidity が 60.2 歳，mortality が 70.3 歳であり，mortality は他に比 較して有意に高齢であった $(p<0.01)$. また， 59 歳以下， 60 歳代，70 歳以上の三層に分けた検討でも mortality は 70 歳以上で有意に高率であった $(p<0.05)$ 。しかし， mor bidityについては年齢は統計学的に有意ではなかった。

性については， mortalityの全例が男性であり有意な因

Table 4 Summary of complicated cases

\begin{tabular}{|c|c|c|c|c|c|c|}
\hline & Case & Age & Sex & Aneurysm & New event & Cause \\
\hline \multirow[t]{6}{*}{$\begin{array}{l}\text { Transient } \\
\text { morbidity }\end{array}$} & 22 & 53 & M & LtMCA & infarction & $\begin{array}{l}\text { occlusion of lenticostriate } \\
\text { arteries }\end{array}$ \\
\hline & & & & LtICPC & & \\
\hline & 25 & 54 & $\mathrm{~F}$ & LtMCA & $\begin{array}{l}\text { hemiparesis } \\
\text { deteriorated }\end{array}$ & $\begin{array}{l}\text { retraction? } \\
\text { (no new lesion on } \mathrm{CT} \text { ) }\end{array}$ \\
\hline & 48 & 64 & M & LtMCA & infarction & kinking of MCA branch \\
\hline & & & & LtICPC & & \\
\hline & 56 & 66 & $\mathrm{~F}$ & RtMCA & brain swelling & injury of Sylvian vein \\
\hline \multirow[t]{2}{*}{$\begin{array}{l}\text { Permanent } \\
\text { morbidity }\end{array}$} & 40 & 60 & $\mathrm{~F}$ & $\begin{array}{l}\text { A com } \\
\text { RtMCA }\end{array}$ & infarction & occlusion of Heubner artery \\
\hline & 52 & 64 & $F$ & RtICOpth & $1 / 4$ anopia & optic nerve compression by clip \\
\hline \multirow[t]{3}{*}{ Mortality } & 60 & 68 & M & LtMCA & delayed $\mathrm{ICH}$ & retraction? \\
\hline & 61 & 70 & M & RtMCA & infarction & occlusion of one of M2 \\
\hline & 67 & 73 & M & LtMCA & $\begin{array}{l}\text { hemorrhagic } \\
\text { infarction }\end{array}$ & stenosis of MCA \\
\hline
\end{tabular}


Table 5 Patients' risk factors (n.s.: not significant)

\begin{tabular}{|c|c|c|c|c|c|c|}
\hline & & & Good & Morbidity & Mortality & Statistic significnce \\
\hline \multirow[t]{3}{*}{ Age } & \multicolumn{2}{|c|}{-59} & 35 & 2 & 0 & \\
\hline & \multicolumn{2}{|c|}{$60-69$} & 18 & 4 & 1 & n. s. \\
\hline & \multicolumn{2}{|c|}{$70-79$} & 14 & 0 & 2 & $p<0.05$ for mortality \\
\hline \multirow[t]{2}{*}{ Sex } & \multicolumn{2}{|c|}{ Male } & 22 & 2 & 3 & $p<0.05$ for mortality \\
\hline & \multicolumn{2}{|c|}{ Female } & 45 & 4 & 0 & \\
\hline \multirow[t]{3}{*}{ Pre ope } & \multicolumn{2}{|c|}{ ADL 1} & 32 & 3 & 1 & \\
\hline & & 2 & 26 & 2 & 1 & n. s. \\
\hline & & 3 & 9 & 1 & 1 & n.s. \\
\hline \multirow{4}{*}{$\begin{array}{l}\text { Original } \\
\text { disease }\end{array}$} & \multirow{2}{*}{\multicolumn{2}{|c|}{$\begin{array}{l}\text { Ischemic d. } \\
\text { Ruptured a. }\end{array}$}} & 30 & 6 & 3 & $p<0.05$ for morbidity \& mortality \\
\hline & & & 22 & 0 & 0 & \\
\hline & \multicolumn{2}{|c|}{ C. nev. palsy } & 8 & 0 & 0 & \\
\hline & \multicolumn{2}{|c|}{ Others } & 7 & 0 & 0 & \\
\hline \multirow[t]{2}{*}{ Hypertension } & & + & 46 & 5 & 3 & n. s. \\
\hline & & - & 21 & 1 & 0 & \\
\hline \multirow{2}{*}{\multicolumn{2}{|c|}{ Diabetes mellitus }} & + & 14 & 4 & 2 & $p<0.05$ for morbidity \& mortality \\
\hline & & - & 53 & 2 & 1 & \\
\hline
\end{tabular}

子であった $(p<0.05)$. morbidity は男性 2 例，女性 4 例 で有意差はみられなかった。

術前の ADLは，転帰に関係していなかった。

原疾患については, mortality, morbidityの全例が虚血 性脳血管障害であり，いずれに対しても有意な危険因子で あった $(p<0.05)$ ．破裂脳動脈瘤に合併した症例，脳神経 症状，あるいは外傷や慢性的頭痛の精査などで診断された 症例の手術成績はすべて goodであった。

高血圧症の合併は有意な因子ではなかったが，糖尿病合 併例では mortality, morbidity とも有意に高率であった $(p$ $<0.05)$.

\section{3. 動脈瘤因子について(Table 6)}

側については, 右側 38 瘤, 左側 46 瘤, 正中 5 瘤であっ た. mortality 3 瘤中 2 瘤が左側, morbidity 9 瘤中 5 瘤が 左側であり，左側が成績不良の傾向がみられたが有意では なかった。

部位については，mortalityの 3 瘤とも中大脳動脈に位 置しており有意に高率であった $(p<0.05)$. しかし, morbidityについては有意な部位はみられなかった。

脳血管撮影像から計測した動脈瘤の長径の平均は, good $5.1 \mathrm{~mm}$, morbidity $5.3 \mathrm{~mm}$, mortality $8.7 \mathrm{~mm}$ であ り, mortalityでは有意に大きかった $(p<0.05)$.

\section{4. 神経放射線学的因子について (Table 7)}

CT 画像で脳梗塞巣を示すと思われる低吸収域のうち実 測で直径 $9 \mathrm{~mm}$ 以上のものが描出された症例が 33 症例み られた。このうち 5 例が morbidity， 3 例が mortality であ
Table 6 Aneurysmal risk factors

\begin{tabular}{|c|c|c|c|c|c|}
\hline & & Good & Morbidity & Mortality & Statistic significnce \\
\hline \multirow[t]{3}{*}{ Side } & Right & 34 & 3 & 1 & \\
\hline & Left & 39 & 5 & 2 & n.s. \\
\hline & Center & 4 & 1 & 0 & \\
\hline \multirow[t]{3}{*}{ Location } & IC & 40 & 3 & 0 & \\
\hline & MCA & 29 & 5 & 3 & $p<0.05$ for mortality \\
\hline & Acom, ACA & 8 & 1 & 0 & \\
\hline \multirow[t]{5}{*}{ Size } & $-4 m m$ & 33 & 3 & 0 & \\
\hline & $5-9$ & 37 & 5 & 2 & \\
\hline & $10-14$ & 7 & 1 & 1 & \\
\hline & $15-$ & 2 & 0 & 0 & \\
\hline & mean & 5.1 & $\stackrel{5.3}{L_{p}}$ & $.05 \stackrel{8.7}{\lrcorner}$ & \\
\hline
\end{tabular}

り，上記所見のみられなかった 43 症例に比較して有意に 成績不良であった $(p<0.05)$ ．不良症例のうち動脈瘤の反 対側にのみ低吸収域がみられたのは morbidityの 1 例のみ で，他の 7 例は同側のみ 4 例，両側 3 例であった.

脳血管撮影で動脈硬化所見がみられた 35 症例のうちに morbidity 5 例, mortality 3 例と不良例 9 例中 8 例が集中 していた．動脈硬化は morbidty, mortalityのいずれも有 意な危険因子であった $(p<0.05)$.

\section{CEA 併用症例について(Table 8)}

虚血性脳血管障害を原疾患とした症例のうち 7 例は，動 脈瘤と同側あるいは前交通動脈瘤については優位な血流側 の内頸動脈に狭窄がみられ CEA を施行した。CEA は内 シャントを用い, ヘパリン 100U/kg の全身投与下に行っ 
Table 7 Neuroradiological risk factors

\begin{tabular}{lccccl}
\hline & & Good & Morbidity & Mortality & Statistic significance \\
\hline \multirow{2}{*}{ LDA on CT } & + & 25 & 5 & 3 & $\mathrm{p}<0.05$ for morbidity \& mortality \\
& - & 42 & 1 & 0 & \\
\hline \multirow{2}{*}{ Arteriosclerosis } & + & 27 & 5 & 3 & $\mathrm{p}<0.05$ for morbidity \& mortality \\
& - & 40 & 1 & 0 & \\
\hline
\end{tabular}

Table 8 Summary of carotid endarterectomy performed cases

\begin{tabular}{lcccllll}
\hline & Case & Age & Sex & Aneurysm & $\begin{array}{l}\text { Degree of } \\
\text { IC stenosis }\end{array}$ & interval & Outcome \\
\hline CEA $\rightarrow$ Clip & 28 & 56 & M & Lt ICbif & $90 \%$ & 24 days & Good \\
& 34 & 58 & F & Rt ICPC & $50 \%+$ ulcer & 30 & Good \\
& 59 & 68 & M & A com & $75 \%+$ ulcer & 33 & Good \\
& 68 & 73 & F & Lt ICPC & $90 \%+$ ulcer & 22 & Good \\
& 75 & 76 & M & Rt ICPC & $75 \%+$ ulcer & 21 & Good \\
\hline Clip $\rightarrow$ CEA & 24 & 54 & F & Lt MCA & $75 \%$ & 52 & Good \\
& 48 & 64 & M & Lt ICPC & $75 \%+$ ulcer & 64 & Transient morbidity \\
& & & & Lt MCA & & & \\
\hline
\end{tabular}

た５例は CEA を先行し，21〜33 日後に動脈瘤手術を行 い, いずれも転帰は goodであった，2例は動脈瘤手術を 先行し，52〜64 日後にCEA を行ったが，1例で動脈瘤の 術後, 一過性の麻痺の増悪がみられた。

\section{考察}

未破裂脳動脈瘤がみつかった場合，手術を行うか否かは 手術侵襲による morbidity, mortalityと, 自然経過におけ る破裂の危険性を考慮して決定されるべきと思われる。そ のためには, 未破裂脳動脈瘤の手術成績について理解する ことは重要である.われわれの検討では transient morbidity $5.3 \%$, permanent morbidity $2.6 \%$, mortality $3.9 \%$ であり，障害のみられた症例は，すべて虚血性脳血管障害 の精査でみつかった動脈瘤であった。

未破裂脳動脈瘤手術の morbidityについては, 1980 年 代前半までの報告では, Samsonの transient morbidity $14.3 \%$, permanent morbidity $6.3 \%$, Salazar $の 7.9 \%$, Wirthの $6.5 \%$ な゙がみられる19)20)23). 1980 年代後半で は, Rosen $\operatorname{rn} の 4.0 \%$, Heiskanenの $2.3 \%$ な゙, morbidityはより低值になってきていることが示されている 17). mortality については, Jominの $6.0 \%$, Heiskanen の $2.3 \%$ との報告を除き $0 \%$ とするものが多く，未破裂脳動 脈瘤手術の安全性が強調されている ${ }^{8) 9111) 19) 20) 23) 。 こ れ ら ~}$ の結果と比較するとわれわれの成績は，やや不良である. この原因としては，手術対象とした母集団の相違が指摘で きる，われわれの場合には，半数以上が虚血性脳血管障害 106 脳卒中の外科 $20: 1992$
を原疾患としていたが, 上記の報告の対象症例の多くは破 裂脳動脈瘤に合併したものや，脳神経症状によるものであ った，われわれの成績も，虚血性脳血管障害以外について みると, 全例が良好な結果であり, morbidity, mortality とも0\%で, 未破裂脳動脈瘤手術の安全性を確認する結果 となっている.

虚血性血管障害に合併した未破裂脳動脈瘤の手術成績が 不良であることを指摘した報告もみられ，その morbidity については $18.8 \%$ から $36.0 \%$ とするものが多く112)315)15) 16)18), mortalityについても北原の $10.0 \%$, 西嶌の $6.1 \%$, 朝田の $2.9 \%$ な゙手術適応を考えるうえで無視しえない危 険性が示されている3)12)16)，われわれの場合も虚血性脳血 管障害症例に限ると morbidity $15.4 \%$, mortality $7.7 \%$ で あった。

虚血脳では, 不安定な脳循環や, 動脈硬化のため retraction や clipping 操作により血流障害をきたしやすいも のと推測され，このことが手術成績不良の要因と思われる. 実際，われわれの症例でも障害の原因としては，動脈系の 障害や retractionの不適切と思われるものが大部分であっ た.しかし，これらは局所での脳血流や神経生理学的モ二 ターなどを用い, より慎重な手術操作を行うことによりあ る程度改善しうるものと期待できる7)13)14)21)。

また，虚血の主因が内頸動脈にある場合には，CEAに より脳循環を改善しうる場合がある。破裂脳動脈瘤につい ての Sternの検討では, 同側病変の場合には動脈瘤直達手 術を優先し, 対側病変の場合には CEA を先に行うことを 
勧めている ${ }^{22)}$.未破裂瘤と同側の頸動脈病変についての われわれの経験では，CEA を先行した場合には良好な成 績であったが，動脈瘤直達手術を先行した 2 例のうち 1 例 で一過性の障害をきたした。このことは, 虚血脳であって も，脳循環を改善しうる場合には，手術成績の向上が期待 できることを示唆しているように思われる.

転帚不良因子のうち神経放射線学的所見は，いずれも虚 血性脳血管障害と関連したものであり，その危険性を再確 認する結果となっている。したがって，虚血性脳血管障害 を合併した症例では，危険性を十分認識したうえで対処す ることが重要である。

また, 70 歳以上の高齢症例では, 各臓器機能の低下, 脳循環の低下や autoregulation の障害が転帰不良の要因と 思われる．未破裂瘤の生涯破裂率についての Dell の報告 によると 60 歳で $4.68 \%$ であり，70 歳ではさらに低率であ る ${ }^{6)}$. 高齢者では，手術の危険性は高く，一方，破裂の危 険性は低いわけであり，手術は勧められないと思われる。 症例毎の特に慎重な検討が必要である.

中大脳動脈瘤が転帰不良因子であったことについては， 分岐が多くクリッピング操作により生じた思わぬ kinking や狭窄により血流障害をきたす危険性があるためと思われ る. 解剖学的構築から, その危険性は内頸動脈系よりも大 きいと思われる。しかし，これは前述のモニタリングやさ らに慎重な操作により克服しうるものであろう。また，わ れわれの症例では，前交通動脈瘤が少数であったことも影 響している可能性が指摘できる.

ところで，これらの危険因子がないか，あるいは少ない 症例での未破裂脳動脈瘤の手術は良好な成績である。した がって，破裂瘤症例の 50〜 60\%が死亡あるいは社会復帰 不能となり，今なおその mortality および morbidity が高 いことを考慮すると，危険因子の少ない症例では，末破裂 瘤について積極的な対応が望ましいと思われる ${ }^{4)}$ 17).また その際には，十分な経験を持った術者により，より慎重な 配慮のもとに手術が行われるべきである.

一方，虚血性脳血管障害例や高齢者例では，転㷌不良の 症例もみられる。このような症例では, 症例各の破裂の危 険性や全身状態, 動脈瘤の部位・大きさ・形状, 脳循環動 態などをもとにした，特に慎重な治療方針の検討が必要と 思われる。

$$
\text { ま と め }
$$

未破裂脳動脈瘤の直達手術 76 症例の手術成績を検討し た. morbidityは $7.9 \%$, mortalityは $3.9 \%$ てっった. morbidity, mortalityのいずれにも関連する因子として, 虚血性脳血管障害を原疾患とすること, 糖尿病の合併, CT で低吸収域が描出されること, 脳血管撮影で動脈硬化
所見がみられることが指摘された。 また， mortality のみ に関連する因子として 70 歳以上の高齢者, 男性, 中大脳 動脈瘤が指摘され, mortality 症例の動脈瘤は, 有意に大 きかった。

危険因子に乏しい症例では，手術成績は良好であり，未 破裂脳動脈瘤について積極的な対応が適切と思われた。し かし, 虚血性脳血管障害合併例や, 70 歳以上の高齢者で は, 特に慎重な治療方針の検討が必要である.

\section{文献}

1）阿部博史, 小池哲雄, 竹内茂和, ほか：閉塞性脳血管障害 に合併した未破裂脳動脈瘤に対する治療方針．脳卒中の外 科 16: $229-232,1988$

2）青木伸夫, 加川瑞夫, 氏家 弘, ほか：脳梗塞に合併した 脳動脈瘤について。脳卒中の外科 16: 28-31, 1988

3）朝田雅博, 武田直也, 玉木紀彦, ほか：脳虚血疾患に合併 した未破裂脳動脈瘤の治療. 脳卒中の外科 16: 233-237, 1988

4）浅利正二, 山本祐司：未破裂脳動脈瘤. その新しい概念に ついて. Neurol Med Chir (Tokyo) 26: 785-791, 1986

5）浅利正二, 西本 詮, 山本祐司：虚血性脳血管障害に合併 した未破裂脳動脈瘤の外科治療. 脳卒中の外科 16 : 252-256, 1988

6) Dell S: Asymptomatic cerebral aneurysm: Assessment of its risk of rupture. Neurosurgery 10: 162-166, 1982

7) Friedman WA, Kaplan BL, Day AL, et al: Evoked potential monitoring during aneurysm operation: Observations after fifty cases. Neurosurgery 20: 678-697, 1987

8) Heiskanen O: Risks of surgery for unruptured intracranial aneurysms. J Neurosurg 65: 451-453, 1986

9) Heiskanen O, Poranen A: Surgery of incidental intracranial aneurysms. Surg Neurol 28: 432-436, 1987

10）兵頭明夫，水上公宏，田沢俊明，ほか：前交通動脈瘤に対 する手術アプローチへの考察. 112例の脳血管撮影, 手術所 見から. 脳神経外科 12: 469-475, 1984

11) Jomin M, Lesoin F, Lozes G, et al: Surgical prognosis of unruptured intracanial arterial aneurysms. Report of 50 cases. Acta Neurochir (Wien) 84: 85-88, 1987

12）北原茂実, 斎藤 勇, 瀬川 弘, ほか：脳梗塞に合併した 脳動脈瘤の手術. 脳卒中の外科 12: 165-168, 1983

13) Matsuda M, Kidooka M, Nakazawa $T$, et al: Intraoperative monitoring of somatosensory evoked potentials in patients with cerebral aneurysm. Correlation between central conduction time and postoperative neurological status. Neurol Med Chir (Tokyo) 31: 13-17, 1991

14) Mizoi K, Yoshimoto $T$ : Intraoperative monitoring of the somatosensory evoked potentials and cerebral blood flow during aneurysm surgery. Safety evaluating for temporary vascular occlusion. Neurol Med Chir (Tokyo) 31: 318-325, 1991

15）永島雅文, 根本正史, 波出石弘, ほか：虚血性脳血管障害 に合併した未破裂動脈瘤の外科治療. 脳卒中の外科 16 : 219-223, 1988

16）西嶌美知春, 堀江幸男, 原田 淳, ほか: 虚血性脳血管障 害に重複した未破裂脳動脈瘤の外科治療. 脳卒中の外科 16 : 238-245, 1988

17) Rosen $\phi$ rn J, Eskesen V, Schmidt K: Unruptured intracranial aneurysms: An assessment of the annual risk of rupture based on epidemiological and clinical data. Br J Neuro- 
surg 2: 369-378, 1988

18）斎藤博文，山田潔忠，井上 明，ほか：虚血性脳血管障害 に合併した未破裂脳動脈瘤に対する治療方針の検討. 脳卒 中の外科 16: 257-260, 1988

19) Salazar JL: Surgical treatment of asymptomatic and incidental intracranial aneurysms. J Neurosurg 53: 20-21, 1980

20) Samson DS, Hodosh RM, Clark WK: Surgical management of unruptured asymptomatic aneurysms. J Neurosurg 46: $731-734,1977$
21) Schramm J, Koht A, Schmidt G, et al: Surgical and electrophysiological observations during clipping of 134 aneurysms with evoked potential monitoring. Neurosurgery 26: 61-70, 1990

22) Stern J, Whelan M, Brisman R, et al: Management of extracranial carotid stenosis and intracranial aneurysms. J Neurosurg 51: 147-150, 1979

23) Wirth FP, Laws ER, Piepgras D, et al: Surgical treatment of incidental intracranial aneurysms. Neurosurgery 12: 507511,1983 